\title{
A new and aberrant species of Dugesia (Platyhelminthes, Tricladida, Dugesiidae) from Madagascar
}

\author{
Giacinta Angela Stocchino', Ronald Sluys², Renata Manconi' \\ I Dipartimento di Scienze della Natura e del Territorio, Via Muroni 25, University of Sassari, I-07100, Italy \\ 2 Naturalis Biodiversity Center, P.O. Box 9517, 2300 RA Leiden, The Netherlands \\ Corresponding author: Giacinta A. Stocchino (stocchin@uniss.it)
}

Academic editor: Lyubomir Penev | Received 29 April 2014 | Accepted 26 June 2014 | Published 15 July 2014

http://zoobank.org/6E36C136-ODBD-4447-9A9E-18D1C3134FA5

Citation: Stocchino GA, Sluys R, Manconi R (2014) A new and aberrant species of Dugesia (Platyhelminthes, Tricladida, Dugesiidae) from Madagascar. ZooKeys 425: 71-88. doi: 10.3897/zookeys.425.7811

\begin{abstract}
In this paper we report a new species of Dugesia of the family Dugesiidae from Madagascar, representing the fourth species of freshwater planarian known from this global biodiversity hotspot. In some respects the new species is aberrant, when compared with its congeners, being characterized by a head with smoothly rounded auricles, a peculiar course of the oviducts, including the presence of a common posterior extension, and by the asymmetrical openings of the vasa deferentia at about halfway along the seminal vesicle. Further, it is characterized by a ventral course of the ejaculatory duct with a terminal opening, very long spermiducal vesicles and unstalked cocoons. Its diploid chromosome complement with 18 chromosomes represents an uncommon feature among fissiparous species of Dugesia.
\end{abstract}

\section{Keywords}

Tricladida, Dugesia, Madagascar, morphology, karyology, reproduction, new species

\section{Introduction}

Madagascar, the fourth largest island in the world, is one of the priority global hotspots for biodiversity conservation (Mittermeier et al. 2004, Vieites et al. 2009) with $5 \%$ of the total species in the world and a very high percentage of endemism $(70 \%)$. 
Unfortunately, this outstanding species richness is greatly endangered, due to rapidly increasing deforestation, soil erosion, and habitat destruction in large areas of the island (Harper et al. 2007, Andreone et al. 2008). This is particularly true for freshwater environments and their communities of benthic invertebrates.

It has been shown that Madagascar represents a global biodiversity hotspot for land planarians (Sluys 1998, 1999) but, unfortunately, freshwater triclads have received much less attention. With respect to freshwater planarians only representatives of the genus Dugesia Girard, 1850 of the family Dugesiidae Ball, 1974 have been reported from Madagascar. This genus is present with three species, two of which are endemic, viz. Dugesia debeauchampi De Vries, 1988, D. myopa De Vries, 1988, and D. milloti De Beauchamp, 1952 (cf. De Beauchamp 1952, De Vries 1988, Stocchino et al. 2002) (Table 1). The first species is known only from the type locality, Nosy Bé Island, north-west of Madagascar. Dugesia myopa is reported from two localities, viz. Andranoboka Cave, northwest of Mahajanga, and from Andringitra, in the southeast of the island. In contrast, $D$. milloti is recorded from widely scattered Madagascan localities, viz. Montagne d'Ambre, Ivohibe, Morafenobé, and occurs also on the island of Anjouan in the Comoros Archipelago (De Beauchamp 1952, De Vries 1988).

A recent field survey performed by one of us (R. Manconi) on the presence and distribution of Madagascan aquatic invertebrates in some unexplored lentic or lotic freshwaters of the High Plateau and the oriental slope (31 sites) yielded several new records of planarians, suggesting that species richness of this taxon in the island is underestimated.

In this paper we describe a new, and in some respects aberrant, species of Dugesia that was identified on the basis of morphological and karyological data. This contribution represents a first step of a more comprehensive faunistic and taxonomic study of planarian populations on Madagascar. An integrative taxonomic analysis, including molecular and morphological data, is in progress in order to analyze in more detail the problematic position of Madagascan freshwater triclads in an historical biogeographic scenario involving the splitting of Gondwana (cf. Sluys et al. 1998).

\section{Materials and methods}

The collected specimens were transferred to the laboratory and were reared in glass bowls under semi-dark conditions at $18+/-2{ }^{\circ} \mathrm{C}$; the worms were fed with fresh beef liver.

For morphological study specimens were fixed for 24 hours in Bouin's fluid, dehydrated in an ascending ethanol series, cleared in clove oil, and embedded in synthetic paraffin. Serial sections were made at intervals of $6-8 \mu \mathrm{m}$ and were stained with Mallory-Cason. Reconstructions of the copulatory apparatus were obtained by using a camera lucida attached to a compound microscope.

For karyological analyses metaphasic plates were obtained by the squashing method and also air drying (splashing), following Vacca et al. (1993). The squashing method 
Table I. Annotated checklist of Madagascan freshwater triclads.

\begin{tabular}{l|l|l}
\hline Taxa & Geographic Distribution and Habitat & References \\
\hline Dugesiidae Ball, 1974 & & \\
\hline Dugesia Girard, 1850 & & \\
\hline $\begin{array}{l}\text { Dugesia bifida Stocchino } \\
\text { \& Sluys, 2014 }\end{array}$ & $\begin{array}{l}\text { small unnamed tributary of the Mania River (type locality), } \\
\text { southern branch of the High Tsiribihina hydrographic basin, } \\
\text { western slope, south-east Madagascar, coll. R. Manconi, } \\
\text { September 2011 }\end{array}$ & present paper \\
\hline $\begin{array}{l}\text { Dugesia debeauchampi } \\
\text { De Vries, 1988 }\end{array}$ & $\begin{array}{l}\text { Teyiamarango Stream (type locality), Nosy Bé Island, north } \\
\text { Madagascar, coll. F. Starmühlner, 1958 }\end{array}$ & De Vries 1988 \\
\hline $\begin{array}{l}\text { Dugesia milloti } \\
\text { De Beauchamp, 1952 }\end{array}$ & $\begin{array}{l}\text { Morafenobé, Mahajeby Forest (type locality), Manambaho } \\
\text { hydrographic basin, western slope, central-west Madagascar, } \\
\text { coll. M. Paulian; Ivohibe, eastern slope, south-east Madagascar, } \\
\text { coll. J. Millot, 1950; Mutsamudu Fall, Anjouan, Comoros } \\
\text { Archipelago, coll. J. Millot, October 1953; Roussette Stream, } \\
\text { Montagne d'Ambre area, north-eastern slope and Ambre, north } \\
\text { Madagascar, 17 September 1957 }\end{array}$ & De Beauchamp 1952, \\
De Vries 1988
\end{tabular}

was performed on single caudal regenerative blastemas of 10 specimens in order to verify the uniformity of the chromosome complement of the strain. The air drying method was performed on 15 intact specimens, thus yielding good metaphasic plates for karyometrical analysis. The chromosome complement was characterized on the basis of 6 metaphasic plates. Karyometric values were calculated after first arranging the chromosomes according to their gradually decreasing lengths. Relative length was calculated as chromosome length $\times 100 /$ total length of the haploid genome. Centromeric index was calculated as length of short arm $\times 100 /$ total length of the chromosome. Chromosomal nomenclature follows Levan et al. (1964).

The histological material is deposited at Naturalis Biodiversity Center, Leiden, The Netherlands (ZMA collection code), and in the Giacinta A. Stocchino collection (CGAS), University of Sassari.

\section{Abbreviations used in the figures}

bc: bursal canal; ca: common atrium; cb: copulatory bursa; cg: cement glands; $\mathrm{cm}$ : circular muscle; cpe: common posterior oviducal extension; d: diaphragm; du: ductule; e: eye; ed: ejaculatory duct; epg: extra bulbar penial glands; g: gonopore; lm: longitudinal muscle; lob: left oviducal branch; lod: left oviduct; lvd: left vas deferens; ma: male atrium; o: ovary; od: oviduct; ov: oviducal vesicle; pb: penis bulb; pg: penial glands; ph: pharynx; pp: penis papilla; rod: right oviduct; rob: right oviducal branch; rvd: right vas deferens; s: sperm; sg: shell glands; sp: spermatophore; sv: seminal vesicle; spv: spermiducal vesicle; t: testes; tu: tuba; v: vitellarium. 


\section{Results}

\section{Systematic Account}

\section{Order Tricladida Lang, 1884}

Suborder Continenticola Carranza, Littlewood, Clough, Ruiz-Trillo, Baguñà \& Riutort, 1998

Family Dugesiidae Ball, 1974

Genus Dugesia Girard, 1850

\section{Dugesia bifida Stocchino \& Sluys, sp. n.} http://zoobank.org/E72381C7-6FC3-422F-A8DA-1D4D0856B521

Figs 1-7; Tables $1-2$

Material examined. Holotype: ZMA V.Pl. 7189.1, one set of sagittal sections on 8

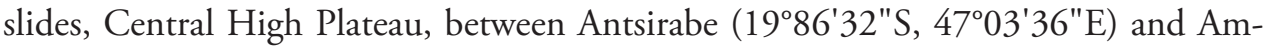
bositra $\left(20^{\circ} 53^{\prime} 14^{\prime \prime} \mathrm{S}, 47^{\circ} 24^{\prime} 61^{\prime \prime E}\right)$, near the small village of Antsariboti, Madagascar, 16 September 2011, coll. R. Manconi.

Paratypes: CGAS Pla 7.1, ibid., sagittal sections on 7 slides; CGAS Pla 7.2, ibid., sagittal sections on 4 slides; CGAS Pla 7.3, ibid., transverse sections on 20 slides. CGAS Pla 7.4-5, ibid., horizontal sections on 4, 7, slides respectively; ZMA V.Pl. 7189.2, ibid., horizontal sections on 6 slides; ZMA V.Pl. 7189.3, ibid., horizontal sections on 3 slides; ZMA V.Pl. 7189.4, ibid., horizontal sections on 4 slides; ZMA V.Pl. 7189.5, ibid., sagittal sections on 7 slides; ZMA V.Pl. 7189.6, ibid., horizontal sections on 5 slides.

Diagnosis. Dugesia bifida is characterized by the presence of the following features: body slender; head with smooth, rounded auricles; oviducts that recurve before opening into the bursal canal and provided with a common posterior extension; slightly asymmetrical openings of the oviducts into the bursal canal; absence of ectal reinforcement; large seminal vesicle; asymmetrical openings of the vasa deferentia into the seminal vesicle, the openings situated at halfway along the vesicle; very long spermiducal vesicles; large diaphragm; ventral course of the ejaculatory duct; terminal opening of the ejaculatory duct; unstalked cocoons; chromosomal number $2 \mathrm{n}=18$.

Etymology. The specific epithet is derived from the Latin adjective bifidus, split into two parts, and alludes to the fact that the peculiar long common oviduct splits into two branches, each branch subsequently opening into the bursal canal.

Geographical distribution. Known only from the type locality in the High Tsiribihina hydrographic basin, Madagascar.

Habitat. Planarians were found in running water in a paddy field area at an altitude ca. $1300 \mathrm{~m}$ asl in the Central High Plateau, along Route Nationale 7, between Antsirabe and Ambositra, near the small village of Antsariboti (Fig. 1). The small, unnamed stream is a tributary of the Mania River in the southern branch of the High Tsiribihina hydrographic basin. The animals, scattered and not abundant, 


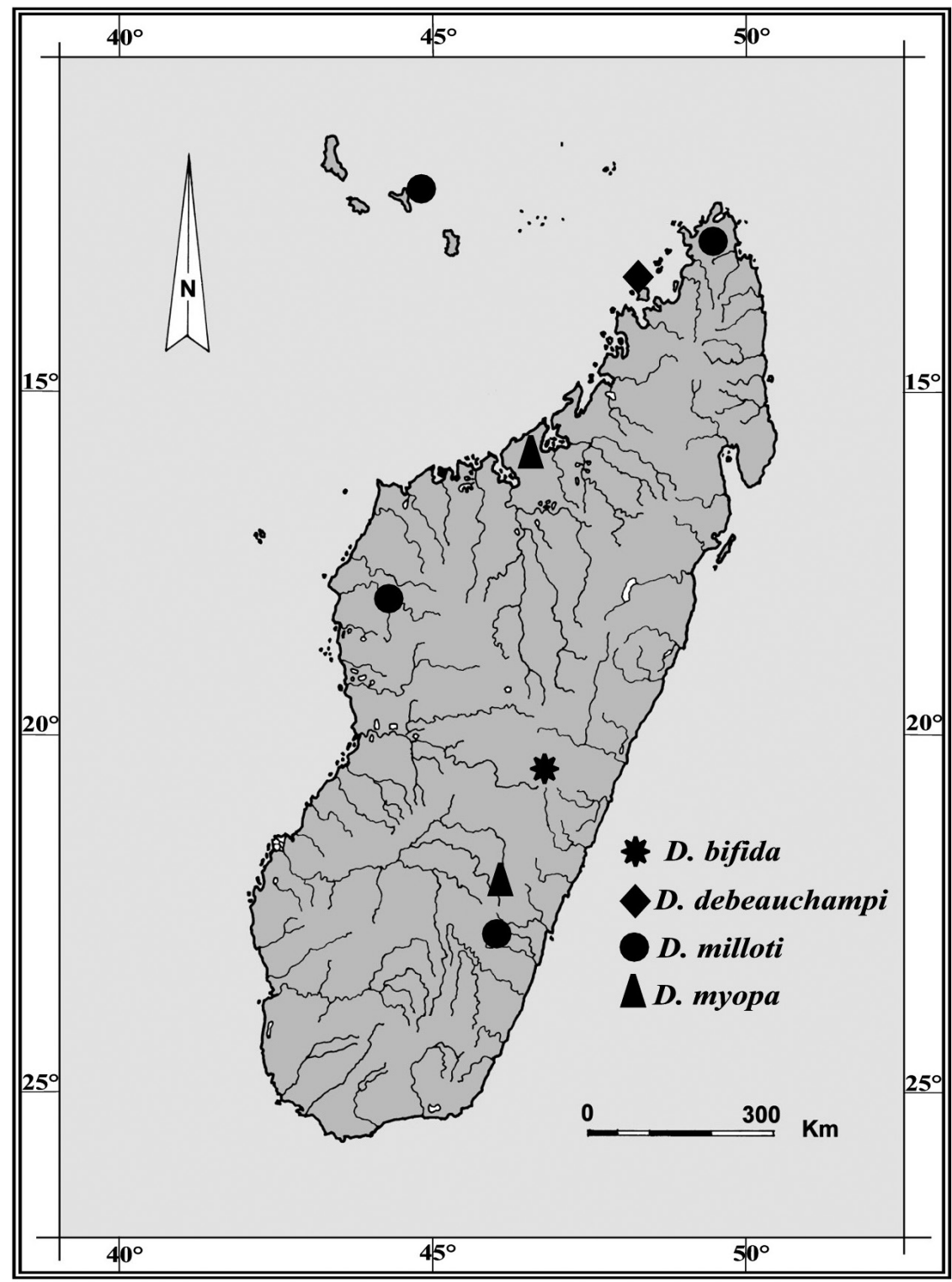

Figure I. Geographic distribution of Dugesia species recorded from Madagascar and adjacent islands. Type locality of $D$. bifida in the High Tsiribihina hydrographic basin indicated by an asterisk.

were collected from running clear water, under small pebbles on coarse sand at a depth of 3-10 $\mathrm{cm}$. A survey of ca. 50 pebbles, performed at the end of the dry season (September), revealed complete absence of planarian cocoons, as well as other invertebrates, excepting very small larvae of mayflies.

Description. Body of living specimens slender, ranging from 6 to $7 \mathrm{~mm}$ in length and $0.4-0.6 \mathrm{~mm}$ in width in fissiparous specimens and from $11-15 \mathrm{~mm} \times 1.5-2 \mathrm{~mm}$ 

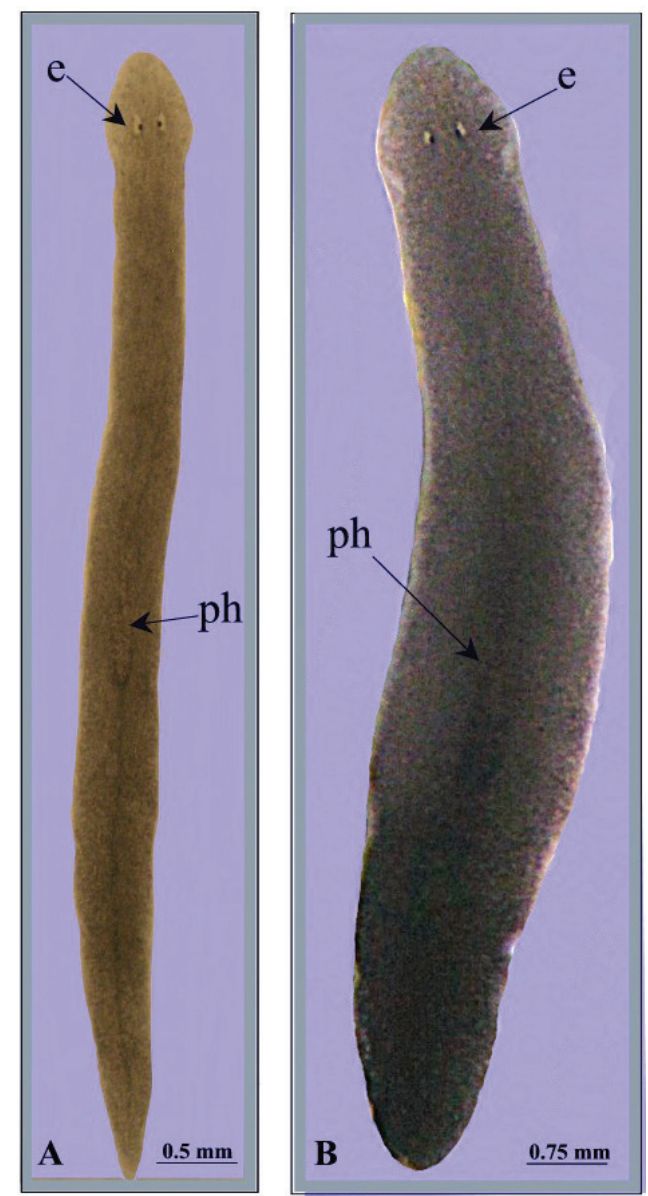

Figure 2. Dugesia bifida. Habitus of living specimens, A fissiparous individual B ex-fissiparous individual.

in sexualized specimens. Two eyes present in the centre of the head; unpigmented auricular grooves marginally placed just posteriorly to the eyes. Head with smooth, rounded auricles and with five sensory fossae on either side of its anterior margin.

The dorsal surface light grey-brown, with two darker lateral stripes running from the central part of the pharynx to its posterior part, where they form a single median stripe that runs to the tail. In sexualized specimens the pigmentation is darker than fissiparous animals (Fig. 2). The ventral surface is paler than the dorsal body surface.

The pharynx is positioned in the posterior half of the body and measures about $1 / 9$ th of the body length. Inner and outer pharyngeal musculature bilayered, i.e. without an extra, third, outer longitudinal muscle layer in the inner sheath of muscles.

The ovaries, localized just behind the brain, are weakly hyperplasic. They occupy half of the dorso-ventral space of the body and are particularly expanded in horizontal direction. The anterior portion of the infranucleated oviducts is expanded into 


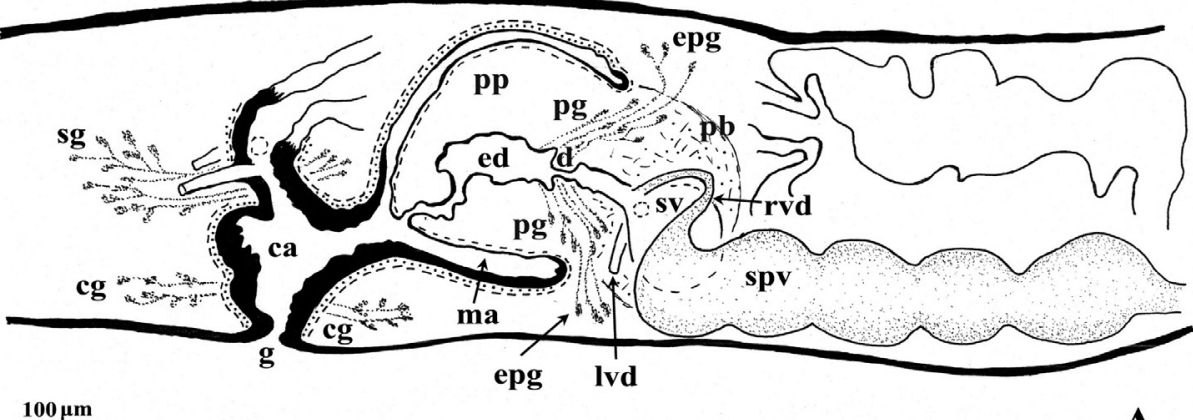

$\underline{100 \mu \mathrm{m}}$

A

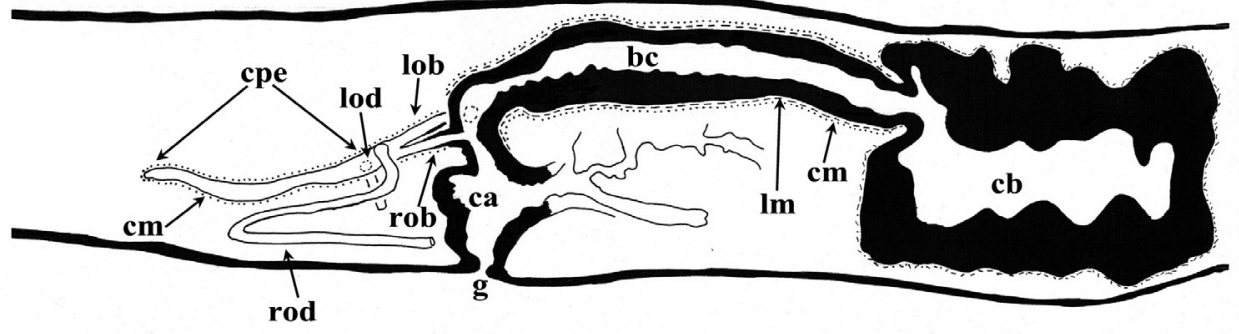

$\underline{100 \mu \mathrm{m}}$

B

Figure 3. Dugesia bifida. Holotype ZMA V.Pl. 7189.1, sagittal reconstructions of the copulatory apparatus (anterior to the right), A male copulatory apparatus $\mathbf{B}$ female copulatory apparatus.

a tuba that may communicate, at a poorly defined position, with the dorsal side of the ovaries or with the center of the ovarian masses, dependent upon the hyperplasic condition of the ovaries (Fig. 6A). The oviducts run ventrally in a caudal direction to beyond the level of the genital pore and, subsequently, recurve anteriad to open at the same level into a long, posterior duct with an histology similar to that of an oviduct. For descriptive purposes we consider this to be a common posterior oviducal extension. The right oviduct opens dorsally into this long common duct while the left oviduct opens ventrally. From this point the common posterior duct divides into two branches, which open separately and asymmetrically through the posterior wall of the bursal canal. The left branch opens slightly dorsally to the right one. The openings of these two branches into the vertically running section of the bursal canal are situated close together (Figs 3A, B, 4). The lumen of the common posterior oviducal extension, and also that of the two branches contains ample sperm. In CGAS Pla 7.1 specimen the most posterior part of the common posterior oviducal extension communicates through a thin ductule with the ventral part of an adjacent vitellarium (Fig. 5C). In the holotype ZMA V.Pl. 7189.1 and in specimens CGAS Pla 7.1 and CGAS Pla 7.2 the 


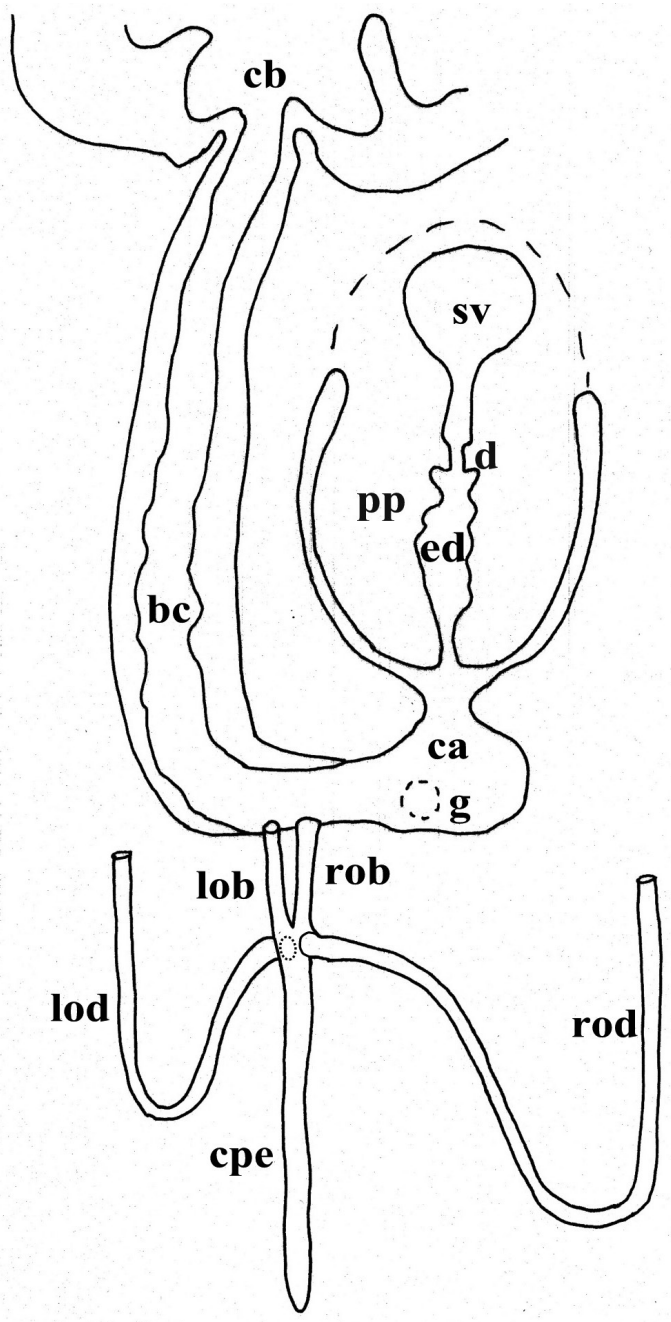

Figure 4. Dugesia bifida. Schematic horizontal reconstruction of the copulatory apparatus.

lumen of the oviducts has an irregular diameter and is generally quite spacious, thus in some parts forming a kind of vesicle (Fig. 6B).

The numerous mature, fully developed testes are situated dorsally and extend from the level of the ovaries to the posterior end of the body. Spermatogenesis appears to proceed in a regular fashion, in that no anomalies, such as irregularly shaped spermatids and spermatozoa, were observed (Fig. 6C). Vitellaria are located between the testes and the intestinal branches and extend to some distance posteriorly to the copulatory apparatus.

The large copulatory bursa is lined by a columnar, glandular epithelium bearing basal nuclei and it is surrounded by a layer of muscles. In the holotype ZMA V.Pl. 7189.1 a spermatophore full of sperm is present in the lumen of the bursa. From the postero-dorsal wall of the bursa the bursal canal runs in a caudal direction to the left 

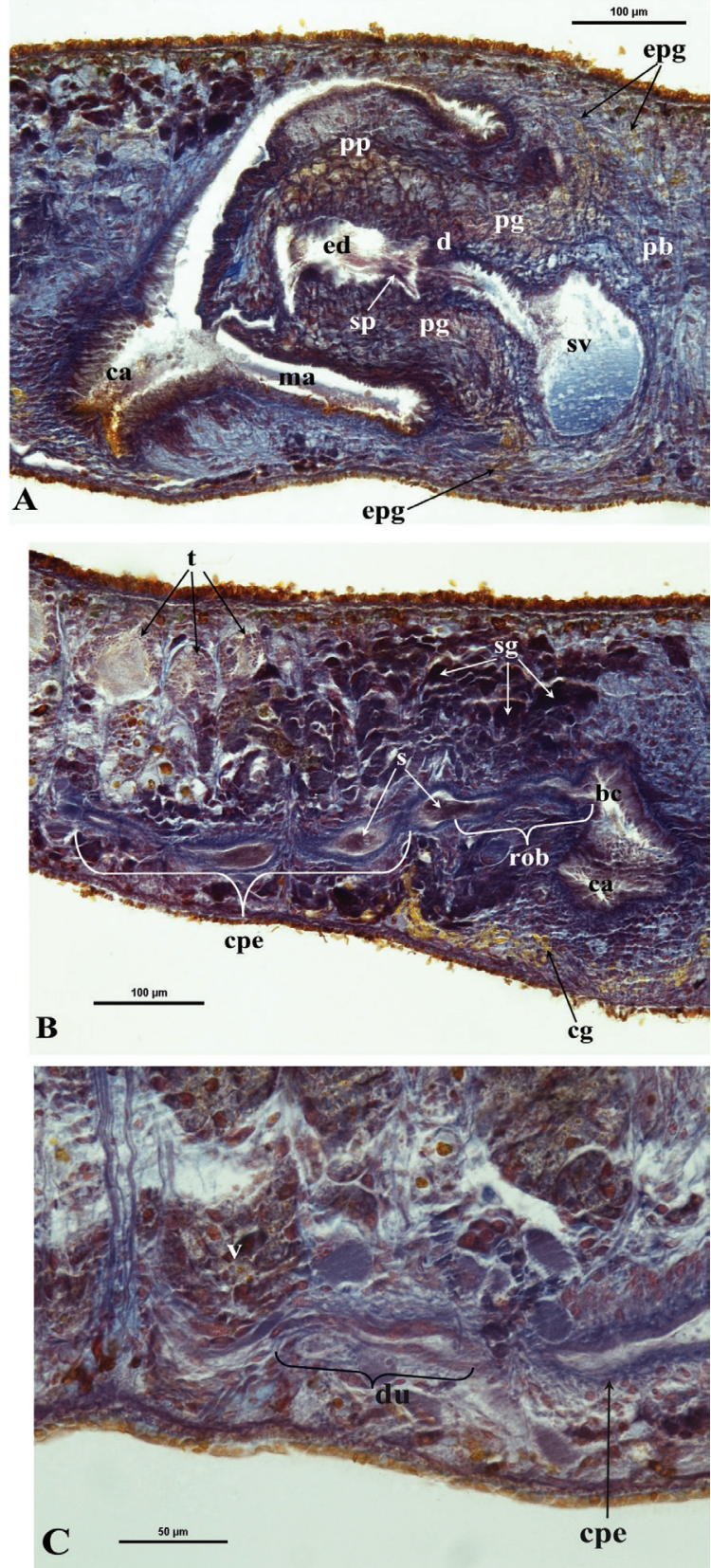

Figure 5. Dugesia bifida. Microphotographs of the copulatory apparatus. A Holotype ZMA V.Pl. 7189.1, sagittal section showing the penis bulb (pb) and the penis papilla (pp) with the seminal vesicle (sv) and the ejaculatory duct (ed) B Holotype ZMA V.Pl. 7189.1, sagittal section showing the opening of the right oviducal branch (rob) through the posterior wall of the bursal canal (bc), and the common posterior oviducal extension (cpe) full of sperm (s) C Paratype CGAS Pla 7.1, sagittal section showing the caudal part of the common posterior oviducal extension (cpe) and the ductule (du) communicating with the ventral part of an adjacent vitellarium (v). 

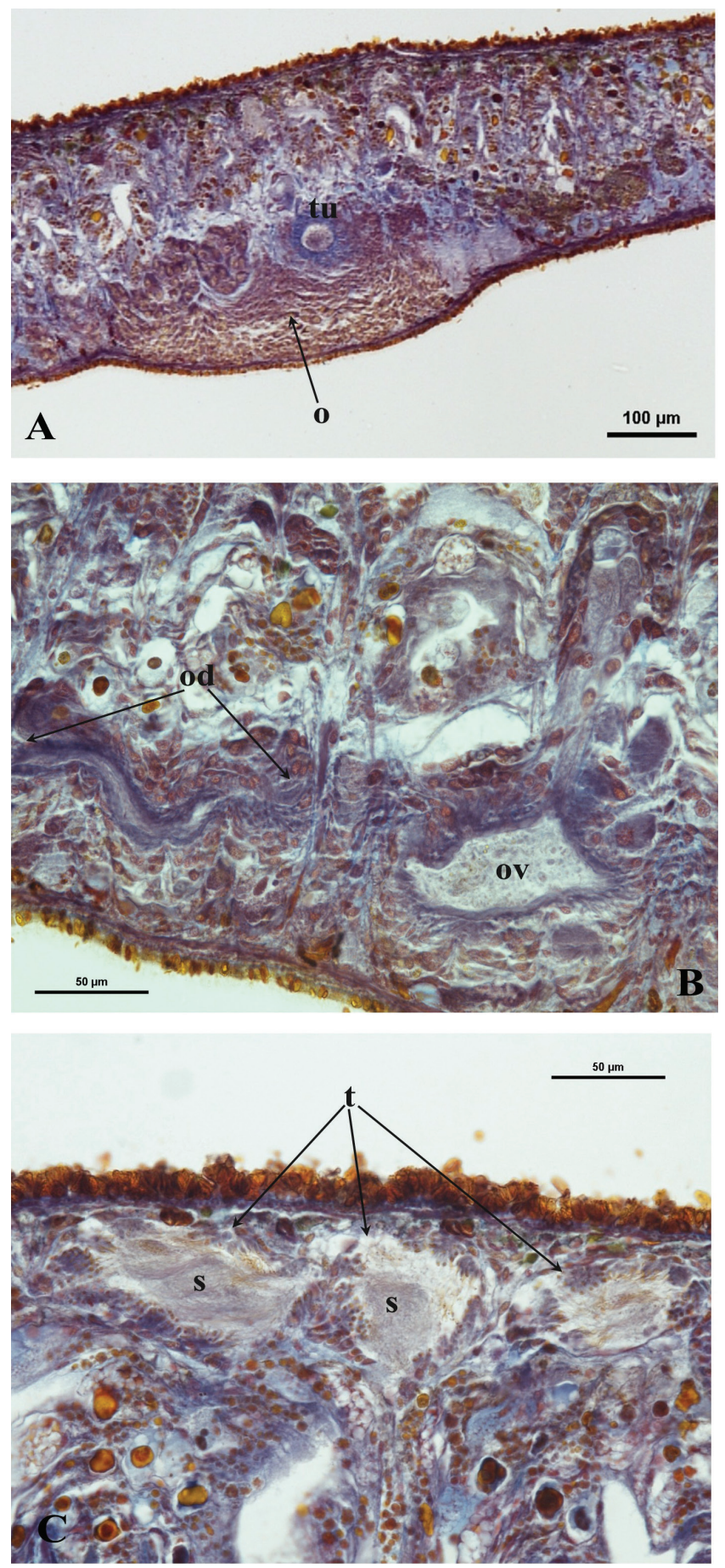

Figure 6. Dugesia bifida. A Holotype ZMA V.Pl. 7189.1, microphotograph of the right hyperplasic ovary (o) with the tuba (tu) B Paratype CGAS Pla 7.1, microphotograph of the oviduct (od) with an expansion (ov) C Holotype ZMA V.Pl. 7189.1, microphotograph of mature testes ( $\mathrm{t}$ ) with sperm (s). 
of the copulatory apparatus and, after a narrowing, communicates with the common atrium. The bursal canal is lined with cylindrical, infranucleated, ciliated cells and is surrounded by a thin subepithelial layer of longitudinal muscles, followed by a layer of circular muscles. Ectal reinforcement is absent. The very abundant shell glands open into the vaginal section of the bursal canal, at the level of the oviducal openings (Figs 3A, 5B).

The scarcely developed penis bulb, rich in glands, consists of intermingled longitudinal and circular muscle fibres. Extra-bulbar penial glands (staining yellow with Mallory-Cason) penetrate the penis bulb at its dorsal and ventral side. The penis bulb houses a very large, flask-shaped seminal vesicle, lined with a nucleated epithelium (Figs 3A, 5A). The vasa deferentia penetrate the proximal, anterior section of the penis bulb and open separately and asymmetrically into the seminal vesicle at a position about halfway along the vesicle, at the point where it narrows. The right vas deferens opens dorsally to the left one. The seminal vesicle opens into the ejaculatory duct via a large, valve-like diaphragm. In all specimens examined the sperm ducts form welldeveloped spermiducal vesicles, packed with sperm. These vesicles are very long and extend over a large distance, viz. from the root of the pharynx to the penis bulb. The diaphragm, located approximately at the base of the penis papilla, receives the openings of penis glands. The stubby, asymmetrical penis papilla is covered by an infranucleated epithelium that is underlain with a subepithelial layer of longitudinal muscles. The ejaculatory duct follows a ventral course and has a terminal opening. A ventrally displaced course of the ejaculatory duct is present in all specimens examined, albeit that this condition is more clearly expressed in some specimens as compared to others, depending on the state of contraction of the penis papilla. For example, in paratype V.Pl. 7189.5 the penis papilla is cone-shaped and shows a distinctly ventrally displaced ejaculatory duct, with a terminal opening. A similar situation is present in paratype CGAS Pla 7.2. In contrast, in the holotype and in paratype CGAS Pla 7.1 the penis papilla is much more stubby, due to contraction, with the result that the ventral course of the ejaculatory duct is much less pronounced. The ejaculatory duct, which in most of the specimens examined contained an empty spermatophore, is lined by a cuboidal, infranucleated epithelium (Figs 3, 5A).

The genital atrium is divided into a common atrium and a male atrium and is lined by an infranucleated epithelium that is underlain by a subepithelial layer of circular muscles, followed by a layer of longitudinal muscle fibres. The common atrium opens ventrally through the gonopore, which receives the openings of the cement glands (Figs 3A, B, 5A, B).

\section{Karyology}

Metaphasic plates revealed that the specimens constantly showed a set of 18 chromosomes. Chromosomes from six metaphasic plates could be arranged, according to their length, into nine groups of two chromosomes with a diploid chromosome set 

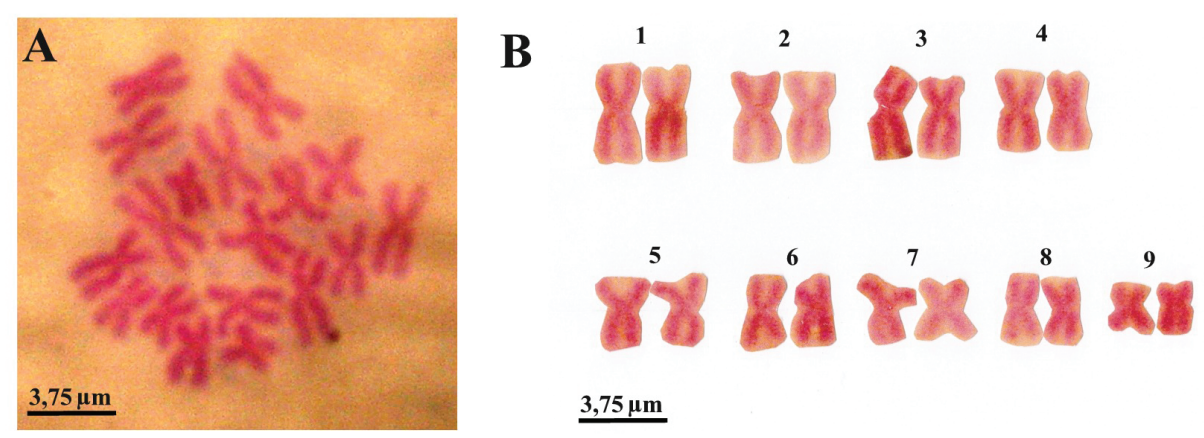

C

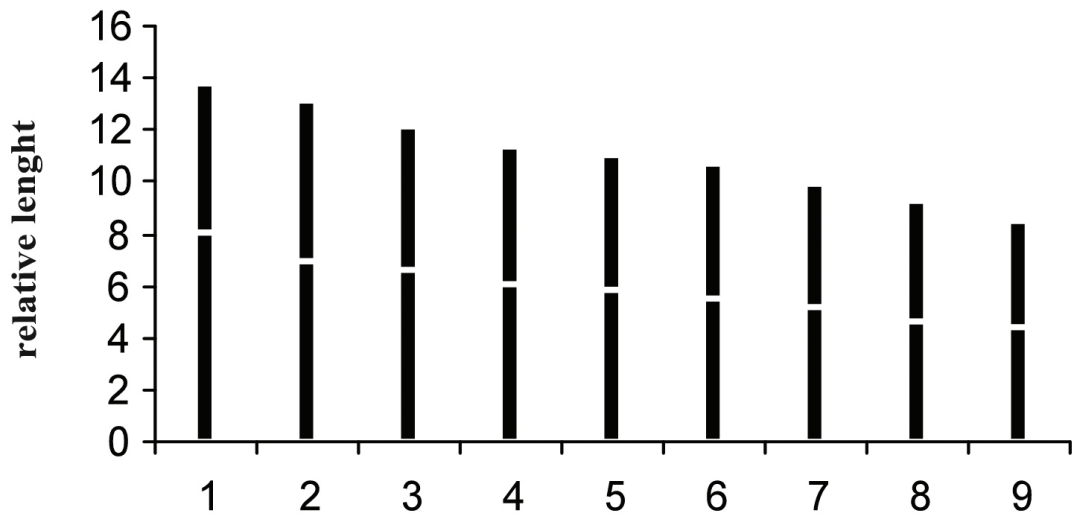

chromosomes

Figure 7. Dugesia bifida. A metaphasic plate B karyogram C idiogram.

Table 2. Dugesia bifida. Mean values and standard deviations of the relative length (r. l.) and centromeric indices (c. i.).

\begin{tabular}{c|c|c|c|c|c|c|c|c|c}
\hline \multicolumn{10}{c}{ Chromosome } \\
\hline & $\mathbf{1}$ & $\mathbf{2}$ & $\mathbf{3}$ & $\mathbf{4}$ & $\mathbf{5}$ & $\mathbf{6}$ & $\mathbf{7}$ & $\mathbf{8}$ & $\mathbf{9}$ \\
\hline \multirow{2}{*}{ r.l. } & $13.84 \pm$ & $13.12 \pm$ & $12.14 \pm$ & $11.38 \pm$ & $11.06 \pm$ & $10.65 \pm$ & $9.98 \pm$ & $9.27 \pm$ & $8.49 \pm$ \\
& 0.68 & 0.41 & 0.45 & 0.16 & 0.34 & 0.40 & 0.37 & 0.20 & 0.57 \\
\hline \multirow{2}{*}{ c.i. } & $41.55 \pm$ & $47.04 \pm$ & $45.46 \pm$ & $47.04 \pm$ & $47.54 \pm$ & $48.36 \pm$ & $48.23 \pm$ & $49.50 \pm$ & $48.06 \pm$ \\
& 3.40 & 1.73 & 3.35 & 1.04 & 2.72 & 2.68 & 1.57 & 1.20 & 1.59 \\
\hline
\end{tabular}

of $2 n=18 ; n=9$. Analysis within each group of chromosomes revealed uniformity in both length and centromeric position. Chromosomal length decreases gradually, with low standard deviation values. Centromeric indices showed great variation, in particular for some chromosomes that exhibit high standard deviations, such as numbers 1 and 3 (Fig. 7, Table 2). 
The karyometric data indicate that the diploid chromosome complement is characterized by metacentric heterobrachial chromosomes, with the exception of chromosome 8 , which is metacentric, bordering on metacentric isobrachial (Table 2).

\section{Life cycle}

The life cycle was monitored for two years under laboratory conditions. All 22 individuals were asexual at collection at the end of the dry season of a particularly arid year (September, 2011). In the laboratory the strain notably increased in numbers due to asexual reproduction by fission. After having been kept in the laboratory for about eight months fissiparous specimens displayed a sexualization process (ca. 4\%) producing ex-fissiparous individuals characterized by hyperplasic ovaries, large body size and development of the copulatory apparatus. This sexualization process, as well as mating, occurred from spring to summer (May-September), followed by fertile cocoon deposition from June to November. After a growth phase of ca. three months, the juveniles divided repeatedly, thus producing new fissiparous clones. After cocoon deposition, the ex-fissiparous individuals resorbed the copulatory apparatus and returned to the fissiparous mode. All cocoons are characterized by the absence of a pedicel, and were cemented firmly to the substratum, i.e. to the wall and bottom of the bowls in which the animals were reared.

\section{Discussion}

Dugesia bifida differs from its congeners in its external morphology, in particular the head shape, the peculiar course of the oviducts at the level of the copulatory apparatus, including the presence of a common posterior extension, and in the asymmetrical openings of the vasa deferentia at about halfway along the seminal vesicle. Further, it is characterized also by a ventral course of the ejaculatory duct with a terminal opening, a large seminal vesicle, and unstalked cocoons.

Almost all known species of Dugesia are characterized by a distinctly triangular head with pointed auricles, whereas in $D$. bifida the latter are much more smoothly rounded. The only other species of Dugesia with a peculiar external morphology is D. milloti, which is characterized by a head with a high triangular shape and prominent, pointed auricles. The latter species is known only from Madagascar and from the island of Anjouan in the Comoros Archipelago (De Beauchamp 1952, De Vries 1988). It is remarkable that these two Dugesia species with an aberrant external morphology both occur on Madagascar.

The peculiar condition of the oviducts in D. bifida lies in the fact that the ducts open into a common posterior extension, which anteriorly divides into two branches before opening into the vaginal section of the bursal canal. Such a condition was never reported before for the genus Dugesia. Usually, in this genus the oviducts run in caudal direction and at the level of the copulatory apparatus open symmetrically or asymmetrically into the vaginal part of the bursal canal. Exceptions to this rule are D. myopa 
and D. congolensis De Beauchamp, 1951 from the Afrotropical Region, D. mertoni (Steinmann, 1914) from the Australasian region, D. deharvengi Kawakatsu \& Mitchell, 1989, and D. andamanensis (Kaburaki, 1925) from the Oriental Region, in which the oviducts fuse to form a short common oviduct before opening into the bursal canal. Two other species, viz. D. lindbergi De Beauchamp, 1959 from the Palaearctic and Oriental regions and D. uenorum Kawakatsu \& Mitchell, 1995 from the Australasian Region are characterized by a polymorphism concerning symmetrical openings and a common oviducal condition (cf. Sluys et al. 1998).

That in D. bifida the common posterior extension belongs to the oviducts is demonstrated by the fact that the histological architecture of this common duct is the same as the rest of the oviducts. The continuation of the oviducts caudally to the copulatory apparatus may be functionally related to the presence of vitellaria in the tail region.

This common posterior extension of the oviducts in D. bifida reminds one of the caudally branched oviducts reported for some other genera of the Dugesiidae viz. Spathula Nurse, 1950 from New Zealand and Australia, Reynoldsonia Ball, 1974, and Eviella Ball, 1977 from Australia, and three species of the genus Romankenkius Ball, 1974 from Tasmania (cf. De Vries and Sluys 1991, Sluys 2001). According to Sluys' (2001) phylogenetic analysis, presence of caudally branched oviducts could be considered as a synapomorphy for a group comprising the genera Spathula, Eviella, and Reynoldsonia, albeit that there are also three cases of parallelism, viz. Romankenkius sinuosus Sluys \& Kawakatsu, 2001, R. libidinosus Sluys \& Rohde, 1991, and R. pedderensis Ball, 1974 [note that this interpretation differs somewhat from that discussed by Sluys (2001, p. 70)].

Caudally branched oviducts occur also in other species belonging to different freshwater families, such as the dendrocoelid Macrocotyla glandulosa Hyman, 1956 and the cavernicolan Rhodax evelinae, Marcus, 1946 (cf. Sluys 2001).

Among African and Madagascan species of Dugesia absence of ectal reinforcement in D. bifida is shared only with D. aethiopica Stocchino et al., 2002 and D. afromontana Stocchino \& Sluys, 2012 (Stocchino et al. 2002, 2012).

From Madagascar only three species of Dugesia have been reported up to this moment, viz. Dugesia debeauchampi, D. milloti, and D. myopa (De Beauchamp 1952, De Vries 1988) (Table 1). In contrast to D. bifida, a central course of the ejaculatory duct is displayed by these three species, while $D$. myopa also has a short common oviduct and reduced eyes. Dugesia bifida shares with D. milloti and D. myopa a large diaphragm, whereas $D$. debeauchampi has a small diaphragm.

As for life history, the life cycle of $D$. bifida under laboratory conditions is comparable to that of other African species, such as D. aethiopica and D. afromontana, in which post-pharyngeal transverse fissioning occur continuously, while sexual reproduction followed by fertile cocoon deposition is less frequent, involving only a small percentage of individuals. In contrast to D. aethiopica, ex-fissiparous specimens of D. bifida do not retain the fissioning ability during their sexual state (cf. Stocchino and Manconi 2013).

In those species of Dugesia in which ex-fissiparous specimens develop from fissiparous strains, these sexualized individuals are characterized by the presence of hyperpla- 
sic ovaries and underdeveloped testes, in which germ cells show degenerative processes (cf. Stocchino et al. 2012). In contrast, in D. bifida the testes are well developed in all specimens examined, without anomalies of the germ cells. Moreover, the hyperplasic ovaries in D. bifida are not visible through the dorsal body wall of living animals, in contrast with other species, such as D. sicula Lepori, 1948, D. maghrebiana Stocchino et al., 2009, D. aethiopica, D. afromontana, and D. arabica Harrath \& Sluys, 2013 (Stocchino et al. 2012, Stocchino and Manconi 2013, Harrath et al. 2013). This may be due to the fact that in $D$. bifida the hyperplasic ovaries are more weakly developed and more expanded in horizontal direction than in vertical direction.

The cocoons of $D$. bifida are unstalked but firmly attached by cement to the substratum. The production of unstalked cocoons is an uncommon condition in the genus Dugesia, for which they are generally reported as being provided with a pedicel and a terminal plate (Gourbault 1972, Ball and Reynoldson 1981). Among dugesiids, stalked cocoons are known also from Schmidtea Ball, 1974 (cf. Gourbault 1972), Cura Strand, 1942 (Ball 1974, Grant et al. 2006), and Girardia dorotocephala (Woodworth, 1897) (cf. Gourbault 1972). In Spathula ochyra Ball \& Tran, 1979 the cocoons are enclosed in a jelly-like dome, attached to the substratum (Grant et al. 2006). Unstalked cocoons that can be fastened to the substratum very lightly or attached firmly to it by cement, are reported for the dugesiid genus Neppia Ball, 1974, the planariid genera Phagocata Leidy, 1847 and Seidlia Zabusov, 1911, and the dendrocoelid genus Dendrocoelopsis Kenk, 1930. Specifically, unstalked cocoons have been reported for the planariid species Planaria torva (Müller, 1774), Polycelis nigra (Müller, 1774), P. tenuis Ijima, 1884, P. felina (Dalyell, 1814), and Crenobia alpina (Dana, 1776), and for the dendrocoelids Bdellocephala punctata (Pallas, 1774), Dendrocoelum lacteum (Müller, 1774), D. album (Steinmann, 1910), D. romanodanubialis (Codreanu, 1949), and D. vesiculosus Stocchino \& Sluys, 2013, (Gourbault 1972, Ball 1974, Ball and Reynoldson 1981, Stocchino et al. 2013, Kawakatsu pers. comm., Stocchino pers. obs.).

As for karyology, D. bifida shows a diploid chromosome complement of 18 chromosomes with basic number $\mathrm{n}=9$. Among Dugesia species this basic number is shared by only six other species: D. sicula, D. maghrebiana and D. biblica Benazzi \& Banchetti, 1972, from the Mediterranean region; D. arabica from Yemen; D. aethiopica and $D$. afromontana from the Afrotropical region (cf. Stocchino et al. 2004, Stocchino et al. 2012, Harrath et al. 2013).

Dugesia bifida represents the easternmost record of a species with a basic chromosomal number $\mathrm{n}=9$. However, $D$. bifida differs from all of these other species in that it is the only species in which fissiparous specimens exhibit a diploid chromosome complement. Dugesia sicula and D. biblica have sexual and fissiparous populations with diploid and triploid chromosome complements, respectively (Pala et al. 1995, Stocchino et al. 2012). Dugesia afromontana is known only from two fissiparous populations with a triploid chromosome complement (Stocchino et al. 2012). Dugesia maghrebiana is represented by a fissiparous population, characterized by a condition of diffuse mosaicism or mixoploidy, with each individual having triploid and tetraploid cells (Stocchino et al. 2009). The only fissiparous population of D. aethiopica shares 
with D. maghrebiana the condition of mixoploidy, but chromosome complements of the former species are diploid and triploid. Dugesia arabica shows a combination of the above-mentioned conditions, in that it has diploid populations that reproduce sexually, triploid fissiparous populations, and mixoploid (diploid and triploid) populations reproducing sexually as well as by fission (Harrath et al. 2013).

With respect to this group of six species discussed above, it turns out that fissiparous populations are always triploid or mixoploid, while sexual populations are diploid.

The presence of well developed testes with very abundant sperm and weakly hyperplasic ovaries in ex-fissiparous specimens of $D$. bifida may be related to its diploid condition, in that it allows a more regular meiosis. A similar condition was reported for $D$. colapha Dahm, 1967 from Ghana, in which the fissiparous populations that produced ex-fissiparous individuals under laboratory conditions were characterized by regular diploid chromosome complements $(2 \mathrm{n}=16 ; \mathrm{n}=8)$. However, in this case, ex-fissiparous individuals were always sterile, despite their regular gametogenesis (Dahm 1967).

\section{Acknowledgements}

This research was supported by a grant from "Fondazione Banco di Sardegna" and SYNTHESYS, the European Union-funded Integrated Actvities Grant (grant number: NL-TAF 3687) to G.A. Stocchino. We acknowledge financial support from Regione Autonoma Sardegna (RAS-CRP-60215), Ministero dell'Istruzione, dell'Università e della Ricerca (MIUR-PRIN) and from Prof. M. Pala. We are grateful to B. Cadeddu and G.P. Scolafurru for their kind support in the laboratory. We thank Prof. Kawakatsu for sharing information on cocoon morphology. R. Manconi is grateful to Prof. Franco Andreone for useful suggestions and to the staff of the Parc Botanique et Zoologique de Tsimbazaza (Antananarivo), Departement de Biologie Animal (Université d'Antananarivo), and Madagascar Institute for the Conservation of Tropical Environments (MICET, Antananarivo) for their kind cooperation. Mr. Narcisse Ramanitrarivelo is acknowledged for acting as a skilful and friendly guide and driver. Completion of the manuscript was made possible by a grant from Naturalis Biodiversity Center to R. Sluys. Dr. L. Winsor (Townsville, Australia) kindly read the final version of the manuscript.

\section{References}

Andreone F, Carpenter AI, Cox N, du Preez L, Freeman K, Furrer S, Garcia G, Glaw F, Glos J, Knox D, Köhler J, Mendelson JR 3rd, Mercurio V, Mittermeier RA, Moore RD, Rabibisoa NHC, Randriamahazo H, Randrianasolo H, Raminosoa NR, Ramilijaona OR, Raxworthy CJ, Vallan D, Vences M, Vieites DR, Weldon C (2008) The challenge of conserving amphibian megadiversity in Madagascar. PLoS Biol 6: e118. doi: 10.1371 /journal.pbio.0060118 
Ball IR (1974) A new genus of freshwater triclad from Tasmania, with reviews of the related genera Cura and Neppia (Turbellaria: Tricladida). Life Science Contributions Royal Ontario Museum 99: 1-48.

Ball IR, Reynoldson TB (1981) Brithish Planarians. Cambridge University Press, Cambridge, $141 \mathrm{pp}$.

Dahm AG (1967) A new Dugesia "microspecies" from Ghana belonging to the Dugesia gonocephala group, Turbellaria, Tricladida, Paludicola. Arkiv för Zoologi 19: 309-321.

De Beauchamp P (1952) Sur les Dugesia (Turbellariés Triclades) d'Afrique tropicale et de Madagascar. Bulletin de la Société Zoologique de France 77: 362-370.

De Vries EJ (1988) A synopsis of the nominal species of the subgenus Dugesia (Platyhelminthes, Tricladida, Paludicola) from Africa and Madagascar. Zoological Journal of the Linnean Society 92: 345-382. doi: 10.1111/j.1096-3642.1988.tb01729.x

De Vries EJ, Sluys R (1991) Phylogenetic relationships of the genus Dugesia (Platyhelminthes, Tricladida, Paludicola). Journal of Zoology (London) 223: 103-116. doi: 10.1111/j.14697998.1991.tb04752.x

Gourbault N (1972) Recherches sur les Triclades Paludicoles hypogés. Mémoires du Muséum National d'Histoire Naturelle, ser. A Zoologie 73: 1-249.

Grant LJ, Sluys R, Blair D (2006) Biodiversity of Australian freshwater planarians (Platyhelminthes, Tricladida, Paludicola): new species and localities, and a review of paludicolan distribution in Australia. Systematics and Biodiversity 4: 435-471. doi: 10.1017/ S1477200006002064

Harper G, Steininger M, Tucker C, Juhn D, Hawkins F (2007) Fifty years of deforestation and forest fragmentation in Madagascar. Environmental Conservation 34: 325-333. doi: $10.1017 /$ S0376892907004262

Harrath AH, Sluys R, Aldahmash W, Al-Razaki A, Alwasel S (2013) Reproductive strategies, karyology, parasites, and taxonomic status of Dugesia populations from Yemen (Platyhelminthes, Tricladida, Dugesiidae). Zoological Science 30: 502-508. doi: 10.2108/ zsj. 30.502

Levan A, Fredga K, Sandberg AA (1964) Nomenclature for centromeric position. Hereditas 52: 201-220. doi: 10.1111/j.1601-5223.1964.tb01953.x

Mittermeier RA, Robles Gil P, Hoffman M, Pilgrim J, Brooks T, Goettsch Mittermeier C, Lamoreux J, Da Fonseca GAB (2004) Hotspots revisited: Earth's biological richest and most endangered terrestrial ecoregions. CEMEX, Mexico City, Mexico, 390 pp.

Pala M, Vacca RA, Casu S, Stocchino GA (1995) The freshwater planarian Dugesia sicula Lepori from Sardinia (Platyhelminthes, Tricladida). Hydrobiologia 310: 151-156. doi: 10.1007/BF00015533

Sluys R (1998) Land planarians (Platyhelminthes, Tricladida, Terricola) in biodiversity and conservation studies. Pedobiologia 42: 490-494

Sluys R (1999) Global diversity of land planarians (Platyhelminthes, Tricladida, Terricola): a new indicator-taxon in biodiversity and conservation studies. Biodiversity \& Conservation 8: 1663-1681. doi: 10.1023/A:1008994925673

Sluys R (2001) Towards a phylogenetic classification and characterization of dugesiid genera (Platyhelminthes, Tricladida, Dugesiidae): A morphological perspective. In: Littlewood 
DTJ, Bray RA (Eds) Interrelationships of the Platyhelminthes. Taylor \& Francis, London and New York, Systematics Association Special volume Ser 60, 57-73.

Sluys R, Kawakatsu M, Winsor L (1998) The genus Dugesia in Australia, with its phylogenetic analysis and historical biogeography (Platyhelminthes, Tricladida, Dugesiidae). Zoologica Scripta 27: 273-289. doi: 10.1111/j.1463-6409.1998.tb00461.x

Stocchino GA, Manconi R (2013) Overview of life cycles in model species of the genus Dugesia (Platyhelminthes: Tricladida). Italian Journal of Zoology 80: 319-328. doi: 10.1080/11250003.2013.822025

Stocchino GA, Sluys R, Manconi R (2012) A new species of Dugesia (Platyhelminthes, Tricladida) from the Afromontane forest in South Africa, with an overview of freshwater planarians from the African continent. Zootaxa 3551: 43-58.

Stocchino GA, Corso G, Manconi R, Pala M (2002) African planarians: Dugesia aethiopica sp. n. (Platyhelminthes, Tricladida) from Lake Tana (NW Ethiopia). Italian Journal of Zoology 69: 45-51. doi: 10.1080/11250000209356437

Stocchino GA, Manconi R, Corso G, Pala M (2004) Karyology and karyometric analysis of an Afrotropical freshwater planarian (Platyhelminthes, Tricladida). Italian Journal of Zoology 71: 89-93. doi: 10.1080/11250000409356557

Stocchino GA, Sluys R, Marcia P, Manconi R (2013) Subterranean aquatic planarians of Sardinia, with a discussion on the penial flagellum and the bursal canal sphincter in the genus Dendrocoelum (Platyhelminthes, Tricladida, Dendrocoelidae). Journal of Cave and Karst Studies 75: 93-112. doi: 10.4311/2011LSC0252

Stocchino GA, Manconi R, Corso G, Sluys R, Casu S, Pala M (2009) African planarians: Morphology and karyology of Dugesia maghrebiana sp. n. (Platyhelminthes, Tricladida) from Tunisia. Italian Journal of Zoology 76: 83-91. doi: 10.1080/11250000802141683

Vacca RA, Casu S, Pala M (1993) Popolamento planariologico dei fiumi del Nord Sardegna. 2. I cariotipi dei Tricladi d'acqua dolce rinvenuti nel bacino idrografico del fiume Coghinas. Bollettino della Società Sarda di Scienze Naturali 29: 59-73.

Vieites DR, Wollenberg KC, Andreone F, Köhler J, Glaw F, Vences M (2009) Vast underestimation of Madagascar's biodiversity evidenced by an integrative amphibian inventory. Proceedings of the National Academy of Sciences USA 106: 8267-8272. doi: 10.1073/ pnas.0810821106 